\title{
Comparative Efficacy and Reinfection of Albendazole- mebendazole, Albendazole-pyrantel Pamoate, and Mebendazole on Soil-transmitted Helminths
}

\author{
Nirmalia Husin, Ayodhia Pitaloka Pasaribu*, Muhammad Ali, Erwin Suteno, Wilhans Wijaya, Syahril Pasaribu \\ Department of Child Health, Faculty of Medicine, Universitas Sumatera Utara, Medan, Indonesia
}

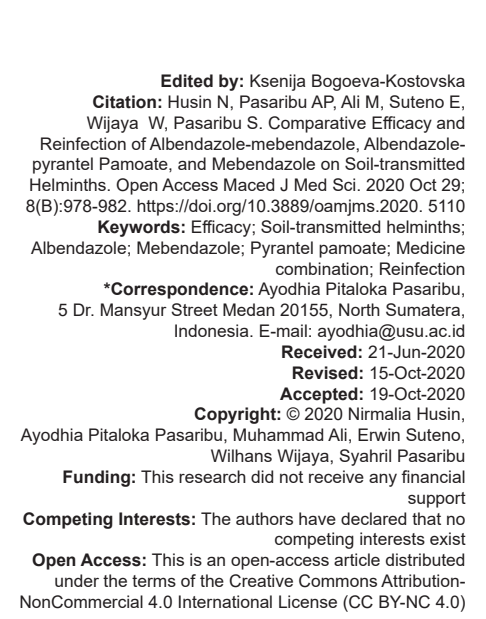

Abstract

BACKGROUND: Soil-transmitted helminths (STHs) infection (i.e., Ascaris lumbricoides, Trichuris trichiura, and hookworm) are commonly found as a single infection as well as a mixture of the three kinds of helminths that requires a broad anthelmintic spectrum. Some study revealed that combination of anthelmintic provides better efficacy.

AIM: The objective of the study was to compare the efficacy of combination treatment of albendazole-mebendazole albendazole-pyrantel pamoate, and mebendazole alone in treating STHs infection as well as the rate of reinfection post-treatment.

METHODS: In 2018, a randomized controlled trial was conducted in Batubara district, North Sumatera. School-aged children diagnosed for STH were randomly allocated to (1) albendazole-mebendazole; (2) albendazole-pyrantel pamoate; or (3) mebendazole treatment groups. Here, we report the efficacy (cure rates [CRs] and egg-reduction rates [ERR]) and reinfection rates determined 12 weeks post-treatment. Chi-square test was used to compare the drug efficacy and reinfection rate between three groups.

RESULTS: A total of 309 children complete baseline and follow-up data. The efficacy was determined after 4 weeks post-treatment albendazole-pyrantel pamoate showed a significant higher efficacy against $A$. lumbricoides (CR: 93.5\%; ERR: 100\%) and T. trichiura (CR: 81.4\%; ERR: 99\%). For hookworm infection, results showed higher efficacy between the three groups after treatment. The reinfection rates 12 weeks after treatment for $A$. lumbricoides infection (Group 1: 3.1\%; 2: 3\%; 3: 1.3\%) with p > 0.05 and for T. trichiura infection (Group 1: $19.2 \% ; 2: 25 \% ; 3: 1.5 \%$ ) with $\mathrm{p}<0.05$

CONCLUSION: This study showed the excellent efficacy of an albendazole-pyrantel pamoate combination against STHs infections. The highest reinfection rate was found in albendazole-pyrantel pamoate group for T. trichiura infection.

\section{Introduction}

Soil-transmitted helminths (STH) infections are one of the common chronic human infections in the world caused by a group of parasitic nematode worms. Infections occur through contact with parasite, eggs, or larvae that thrive in the warm and moist soil of the world's tropical and subtropical countries [1] The three main groups of STHs that infect humans are Ascariasis lumbricoides, Trichuris trichiura, and hookworm (Ancylostoma duodenale and Necator americanus) [2].

The prevalence of STHs infection in Indonesia in 2009 showed that $31.8 \%$ of children suffered from STH infections and survey in 2005 found that the prevalence was 30\% [3], [4]. The prevalence of STH infection in Sumatera Utara in 2012 was 32.3\% [5], and the prevalence in Medan in 2008 was $73 \%$ [6]. Study in Suka Village, North Sumatera, Indonesia, in 2004 found that the prevalence was $91.3 \%$ [7].

STHs infection is commonly found as a single or mixture of three groups of STH [8]. There are some anthelmintics such as albendazole, levamisole, mebendazole, and pyrantel pamoate that are effective against STH infections with their strength and weakness. In implementation, most of STH infection control programs only use benzimidazole such as albendazole and mebendazole [9]. Although one-dose treatment with both drugs shows high efficacy against $A$. lumbricoides, but only albendazole cures a satisfactory proportion of hookworm infections. Both drugs show low efficacy against $T$. trichiura [10]. The combination of albendazolemebendazole and albendazole-oxantel pamoate has emerged as potential therapies against STH infections in a series of randomized controlled trials [11], [10]. These drug combinations were well tolerated and improved the proportions of patients cured of T. trichiura, A. lumbricoides, and hookworm infections. However, drug efficacy is affected by myriad factors (e.g., baseline infection intensity, parasite strain, host factors, and the diagnostic approach used), the findings were difficult to compare and interpret [10], [12], [13]. This study undertook a randomized controlled trial to compare the efficacy and safety of albendazole-mebendazole and 
albendazole-pyrantel pamoate, with standard treatment (one-dose mebendazole), to identify the intervention with the greatest efficacy against STH in elementary school students.

\section{Methods}

This study conducted a randomized, controlled, OpenTrial from July to December 2018 in three primary schools, in Batubara district, North Sumatera.

\section{Inclusion criteria}

Children between 6 and 12 years of age whose stool samples were positive for single infection or co-infection with either A. lumbricoides, T. trichiura, or and hookworm were considered eligible.

\section{Exclusion criteria}

Children who have used anthemintics 1 month before the study were excluded from the study.

\section{Ethical approval}

Ethical approval was obtained from the Health Research Ethics Committee of the Faculty of Medicine, University of Sumatera Utara. Before the commencement of the study, permission was obtained from the school authority. The parents or guardians of the children were invited to the school and informed about the study procedure, including potential benefits and risks. Written informed consent was obtained from the parents or legal guardians and verbal assent from the participating children. Before treatment, the children were examined for clinical signs and symptoms of any existing disease and their weight and height were measured.

\section{Study protocol}

Children were randomly assigned, with the use of randomization table, to receive one of three treatments: Albendazole $400 \mathrm{mg}$ plus mebendazole $500 \mathrm{mg}$, albendazole $400 \mathrm{mg}$ plus pyrantel pamoate $10 \mathrm{mg} / \mathrm{kg}$, or $500 \mathrm{mg}$ of mebendazole. Children, studysite investigators, and laboratory scientists were aware of the randomized study groups. After 4 and 12 weeks of treatment, stool samples were collected from the children for the diagnosis of STH infections. Stool samples were transferred to the laboratory and KatoKatz thick smears were examined by skilled laboratory scientists for eggs of $A$. lumbricoides, T. trichiura, and hookworm. At the end of the study, all children remaining infected received treatment.
Treatment efficacy was assessed 4 weeks after treatment. The efficacy was assessed using cure rates (CRs) and egg reduction rates (ERR). CR was defined as the percentage of individuals who became helminth egg negative after treatment with anthelminthic drugs [10], [14]. Reinfection rates were defined as children positive at baseline, negative 12 weeks, and positive 12 weeks post-treatment [15].

\section{Statistical analysis}

The Chi-square test was used to compare the variable between the treatment group and CRs, ERR, and reinfections. Data processing was performed using Statistical Package for the Social Sciences for Windows (SPSS) version 24.0, 2016 with $p<0.05$ was significance and 95\% confidence interval.

\section{Results}

\section{Study participants}

In total, 840 children who were invited to participate, 676 had complete baseline data. The prevalence of STHs infection was $45.7 \%$ (309/676). We randomly assigned 309 eligible children infected with STHs between, to one of the three treatment groups (Figure 1). Demographic and baseline laboratory characteristics of the 309 children included in the analysis are summarized in Table 1. Treatment groups were well balanced at baseline in terms of age, sex, and nutritional status.



Figure 1: Study flow chart

CRs and ERR among 309 children with STHs infection are shown in Table 2. Treatment with albendazole-pyrantel pamoate resulted in a significantly higher $\mathrm{CR}$ among children with $A$. lumbricoides and T. trichiura infection than did albendazole-mebendazole 
Table 1: Baseline subject characteristics

\begin{tabular}{|c|c|c|c|}
\hline Characteristics & $\begin{array}{l}\text { Albendazole- } \\
\text { mebendazole } \\
(n=110)\end{array}$ & $\begin{array}{l}\text { Albendazole- } \\
\text { pyrantel pamoate } \\
(\mathrm{n}=102)\end{array}$ & $\begin{array}{l}\text { Mebendazole } \\
(\mathrm{n}=97)\end{array}$ \\
\hline Age (year), mean (SD) & $8.3(1.58)$ & $8.9(1.8)$ & $8.8(1.63)$ \\
\hline \multicolumn{4}{|l|}{ Nutritional status, $\mathrm{n}(\%)$} \\
\hline Severe malnutrition & $6(5.5)$ & $3(2.9)$ & $1(1.03)$ \\
\hline Mild malnutrition & $52(47.3)$ & $45(44.1)$ & $35(36.0)$ \\
\hline Well nourish & $47(42.7)$ & $45(44.1)$ & $51(52.5)$ \\
\hline Overweight & $2(1.8)$ & $5(4.9)$ & $5(5.1)$ \\
\hline Obesity & $3(2.7)$ & $4(3.9)$ & $5(5.1)$ \\
\hline \multicolumn{4}{|l|}{ Sex, no (\%) } \\
\hline Male & $56(35.7)$ & $54(34.4)$ & $47(29.9)$ \\
\hline Female & $54(35.5)$ & $48(31.6)$ & $50(32.9)$ \\
\hline \multicolumn{4}{|l|}{ Infection, no (\%) } \\
\hline A. lumbricoides & $28(25.5)$ & $31(30.4)$ & $29(29.9)$ \\
\hline T. trichiura & $103(94.5)$ & 97 (95.1) & $93(95.9)$ \\
\hline Hookworm & $12(10.9)$ & $15(14.7)$ & $8(8.2)$ \\
\hline \multicolumn{4}{|c|}{ EPG feces, median (range) } \\
\hline A. lumbricoides & $831(132-62424)$ & $1512(192-11592)$ & $1342(97-38808)$ \\
\hline T. trichiura & $763(48-19103)$ & $726(48-9786)$ & 772 (72-9657) \\
\hline Hookworm & $21(9-97)$ & $18(8-89)$ & $16(6-39)$ \\
\hline \multicolumn{4}{|l|}{ Multiple infection, no (\%) } \\
\hline Double infection & $32(29.1)$ & $41(40.2)$ & $33(34.0)$ \\
\hline Triple infection & $1(0.9)$ & $0(0.0)$ & $0(0.0)$ \\
\hline
\end{tabular}

and mebendazole ( $A$. lumbricoides $93.5 \%$ vs. $57.1 \%$ vs. $27.6 \%, p<0.05 ;$ T. trichiura $81.4 \%$ vs. $69.2 \%$ vs. $65.6 \%, p<0.05)$. We observed no significant differences between the three-drug combinations with respect to CRs in hookworm infection. Mebendazole monotherapy resulted in a significant lower CR than combination drug, especially in $A$. lumbricoides and T. trichiura infection.

Table 2: Comparison of efficacy between the three groups after treatment

\begin{tabular}{lllll}
\hline Efficacy (\%) & $\begin{array}{l}\text { Albendazole- } \\
\text { mebendazole } \\
(\mathrm{n}=110)\end{array}$ & $\begin{array}{l}\text { Albendazole- } \\
\text { pyrantel pamoate } \\
(\mathrm{n}=102)\end{array}$ & $\begin{array}{l}\text { Mebendazole } \\
(\mathrm{n}=97)\end{array}$ & $\mathrm{P}^{*}$ \\
\hline Efficacy of STH & 69 & 82 & 50 & 0.001 \\
CRs & & & & \\
$\quad$ A. lumbricoides & 57.1 & 93.5 & 27.6 & 0.001 \\
$\quad \begin{array}{l}\text { T. trichiura } \\
\text { Hookworm }\end{array}$ & 69.2 & 81.4 & 65.6 & 0.037 \\
ERRs & 91.7 & 100.0 & 87.5 & 0.605 \\
$\quad \begin{array}{l}\text { A. lumbricoides } \\
\quad \text { T. trichiura }\end{array}$ & 100.0 & 100.0 & 96.6 & 0.357 \\
$\quad$ Hookworm & 99.0 & 99.0 & 100.0 & 0.625 \\
${ }^{*}$ The Chi-square test. A. Iumbricoides: Ascaris lumbricoides, T. trichiura: Trichuris \\
trichiura, STH: Soil-transmitted helminth, CRs: Cure rates, ERR: Egg-reduction rates.
\end{tabular}

After 12 weeks post-treatment, 44 out of 201 (21.9\%) children were reinfected with $A$. lumbricoides and T. trichiura. For A. lumbricoides, the prevalence at baseline was $28.5 \%$ by design. This study observed that 7 of the 88 children $(8 \%)$ were reinfected with A. lumbricoides 12 weeks after treatment. For T. trichiura infection, 37 of the 293 (12.7\%) cured children were found to be reinfected 12 weeks after being treated. All reinfections were of mild intensity. There was a significant difference in the reinfection level of $T$. trichiura infection between three treatment groups, but there was no significant difference in A. lumbricoides reinfections (Table 3 ).

Table 3: The incidence of reinfection after drug administration

\begin{tabular}{cllll}
\hline Reinfection (\%) & $\begin{array}{l}\text { Albendazole- } \\
\text { mebendazole }(\mathrm{n}=110)\end{array}$ & $\begin{array}{l}\text { Albendazole-pyrantel } \\
\text { pamoate }(\mathrm{n}=102)\end{array}$ & $\begin{array}{l}\text { Mebendazole } \\
(\mathrm{n}=97)\end{array}$ & $\mathrm{p}^{*}$ \\
\hline Reinfection, $\mathrm{n}(\%)$ & & & & \\
A. lumbricoides & $3(3.1)$ & $3(3.1)$ & $1(1.3)$ & 0.786 \\
T. trichiura & $15(19.2)$ & $21(25)$ & $1(1.5)$ & 0.001 \\
\hline${ }^{*}$ The Chi-square test. A. lumbricoides: Ascaris lumbricoides, $T$. trichiura: Trichuris trichiura.
\end{tabular}

\section{Discussion}

The prevalence of STHs infection in this study was $45.7 \%$, consisting of $A$. lumbricoides $28.5 \%$, T. trichiura $95.1 \%$, and hookworm $11.3 \%$. However, the prevalence was lower than the reports from the previous study in Medan (2008) was 73\% [6], in Kabupaten Karo (2002) was 95.4\% [14], and 91.3\% (2004) [7]. The prevalence of STHs infection observed in this study was lower than the previous study which may be as a result of the helminthiasis control program by government targeted at preschoolers (1-4-year-old) and elementary school-aged children (5-12-year-old) [3]. T. trichiura infection in our study was higher than the other helminth infections. It may result from the use of albendazole in the helminthiasis control program, which is $T$. trichiura is less sensitive to single-dose albendazole [3], [8], [16].

The treatment for STH single infection has good results, but the treatment for mixed infections shows unsatisfactory results [9]. The meta-analysis comparing CRs of single dosed drugs have various results [11].

Four weeks after treatment, CRs of A. lumbricoides achieved with the combination of albendazole-pyrantel pamoate were 93.5\%, albendazole-mebendazole was $57.1 \%$, and mebendazole was $27.6 \%$. In earlier studies, CR of albendazole-oxantel pamoate, albendazolemebendazole, and mebendazole was $97.7 \%, 100 \%$, and $95.4 \%$, respectively [15]. Another study comparing the CRs after albendazole-oxantel pamoate and mebendazole treatments also demonstrates high CRs, that is, $94.4 \%$ and $91.2 \%$, respectively [10].

Albendazole-pyrantel pamoate had greater efficacy against $T$ trichiura compared with the established standard treatment of one-dose mebendazole. This study shows that the CRs of $T$. trichiura after treated with albendazole-pyrantel pamoate were $81.4 \%$. Previous studies of combinations albendazoleoxantel pamoate documented high efficacy against T. trichiura [10], [12], [15]. The CRs resulted in the previous study are lower than this study, but that result was the highest CRs among the treatment groups in that study.

Albendazole-pyrantel pamoate treatment shows high $\mathrm{CRs}$ from $A$. lumbricoides and T. trichiura because these drugs have different pharmacokinetics and pharmacodynamics, meaning that pyrantel pamoate will disable helminth, and active metabolism of albendazole will kill the worms, eggs, and larva [13], [17], [18], [19]. The CRs of albendazolemebendazole against $A$. lumbricoides and T. trichiura were good in this study. It is resulted by the mechanism of drugs, mebendazole is an active component that will contact with the worm, followed with the metabolism of albendazole, so the worm will have long contact with drugs [14]. 
The CRs of Hookworm showed the greatest efficacy in our study. The CRs achieved with the combination of albendazole-mebendazole were $91.7 \%$, albendazole-pyrantel pamoate was $100 \%$, and mebendazole was $87.5 \%$. This result was different with the previous study. In an earlier study, CRs of albendazole-mebendazole were $48.8 \%$, albendazoleoxantel pamoate was $48 \%$, and mebendazole was $24.4 \%$ [12]. The different can cause of large of sample and parasite strains at the two study sites might account for this contradictory finding.

A study at Tanzania in 2015 that assessed egg reduction in STHs infections reported that reduction of $T$. trichiura and hookworm eggs after treated with mebendazole was unsatisfactory [12]. Egg reduction in our study was good for all treatment groups. Although mebendazole had very poor CRs in this study, it still has great efficacy to reduce the eggs.

In our study, reinfection was found in A. lumbricoides and T. trichiura, but not in hookworms. It can be caused by the life cycle of hookworm that can survive for a few weeks on the soil under suitable conditions [20]. A. lumbricoides and T. trichiura are very durable in the right environmental condition and infective for several months, so individuals can be reinfected from the eggs that survive in the environment [21]. There are significant differences in reinfection of $T$. trichiura between the three treatment groups. In our study, the reinfection rate of $T$. trichiura 12 weeks post-treatment for albendazole-pyrantel pamoate was $25 \%$, albendazole-mebendazole was $19.2 \%$, and mebendazole was $19.2 \%$. In another study, the reinfection rate in mebendazole group was $50 \%$, albendazole-oxantel pamoate was $30.9 \%$, and albendazole-mebendazole was $22.2 \%$ [15].

The reinfection rate in our study was not as high as in the previous study, probably due to various factors that influence the incidence of STH reinfection. STH infection is closely related to poverty, poor hygiene, lack of clean water access, and poor sanitation [22]. These factors also influence reinfection. However, the factors that influence STH reinfection are not report in our study.

\section{Conclusion}

We identified two combination therapies against STHs that have significantly higher efficacy than the standard treatment of mebendazole alone: Albendazole plus pyrantel pamoate and albendazole plus mebendazole. On the one hand, the combination including pyrantel pamoate cured a larger proportion of patients than the combination with mebendazole. This combination could become a key element in controlling STH infections, especially in highly endemic settings.
Further, trials should evaluate reinfection rates with pyrantel pamoate 6 and 12 months after treatment and ideally after several rounds of treatment.

The reinfection rate observed for $A$. lumbricoides and $T$. trichiura is worrying. This finding supports the necessity of integrated control approaches, including regular treatment, improved sanitation and health education, to reduce the burden of STH infections.

\section{References}

1. World Health Organization. Deworming for Health and Development. Report of the Third Global Meeting of the Partners for Parasite Control. Geneva: World Health Organization; 2005.

2. Margono SS. Important human helminthiasis in Indonesia. In Crompton DW, Montresor A, Nesheim MC, Savioli L, editors. Controlling Disease due to Helminth Infections. Geneva: World Health Organization; 2003. p. 3-14.

3. Kementerian Kesehatan Republik Indonesia. Direktorat Jenderal P2PL. Pedoman Pengendalian Kecacingan. Jakarta: Kementerian Kesehatan Republik Indonesia; 2012.

4. Kementerian Kesehatan Republik Indonesia. Rencana Aks Program Pengendalian Penyakit dan Penyehatan Lingkungan Tahun 2015-2019. Jakarta: Kementerian Kesehatan Republik Indonesia; 2015.

5. Dinas Kesehatan Provinsi Sumatera Utara. LaporanAkuntabilitas Kinerja Instansi Pemeritah Dinas Kesehatan Provinsi Sumatera Utara Tahun 2010. Medan: Dinas Kesehatan Provinsi Sumatera Utara; 2011. p. 22-95. https://doi.org/10.32315/ti.8.e025

6. Yunus R. Keefektifan Albendazol Pemberian Sekali Sehari Selama 1, 2, dan 3 Hari dalam Menanggulangi Infeksi Trichuris trichiura Pada Anak Sekolah Dasar di Kecamatan Medan Tembung, Tesis. Medan: Sekolah Pascasarjana Universitas Sumatera Utara; 2008. https://doi.org/10.24114/sejpgsd. v7i3.9253

7. Pasaribu S. Penentuan Frekuensi Optimal Pengobatan Massal Askariasis Dengan Albendazole Pada Anak Usia Sekolah Dasar di Desa Suka, Disertasi. Medan: Program Pasca Sarjana USU; 2004. https://doi.org/10.24114/jkss.v16i31.10174

8. World Health Organization. Report of the WHO Informal Consultation on the Use of Chemotherapy for the Control of Morbidity Due to Soil-Transmitted Nematodes in Humans. Geneva: WHO Division of Control of Tropical Diseases; 2006.

9. Olliaro P, Seiler J, Kuesel A, Horton J, Clark JN, Don R, et al. Potential drug development candidates for human soiltransmitted helminthiases. PLoS Negl Trop Dis. 2011;5(6):e1138. https://doi.org/10.1371/journal.pntd.0001138

PMid:2169524710. Speich B, Ame SM, Ali SM, Alles R Huwyler J, Hattendorf J, et al. Oxantel pamoate-albendazole for Trichuris trichiura infection. N Engl J Med. 2014;370(7):610-20. https://doi.org/10.1056/nejmc1403068

PMid:24521107

11. Keiser J, Utzinger J. Efficacy of current drugs against soiltransmitted helminth infections: Systematic review and metaanalysis. JAMA. 2008;299(16):1937-48. https://doi.org/10.1001/ jama.299.16.1937 PMid:18430913

12. Speich B, Ali SM, Ame SM, Bogoch II, Alles R, Huwyler J, et al. Efficacy and safety of albendazole plus ivermectin, albendazole plus mebendazole, albendazole plus oxantel pamoate, and mebendazole alone against Trichuris trichiura and concomitant 
soil-transmitted helminth infections: A four-arm, randomised controlled trial. Lancet Infect Dis. 2015;15(3):277-84. https://doi. org/10.1016/s1473-3099(14)71050-3

PMid:25589326

13. Horton J. Albendazole: A review of anthelmintic efficacy and safety in humans. Parasitology. 2000;121 Suppl:S113-32. https://doi.org/10.1017/s0031182000007290

PMid:11386684

14. Namwanje $H$, Kabatereine NB, Olsen A. Efficacy of single and double doses of albendazole and mebendazole alone and in combination in the treatment of Trichuris trichiura in school-age children in Uganda. Trans $\mathrm{R}$ Soc Trop Med Hyg. 2011;105(10):586-90. https://doi.org/10.1016/j. trstmh.2011.07.009

PMid:21885077

15. Speich B, Moser W, Ali SM, Ame SM, Albonico M, Hattendorf J, et al. Efficacy and reinfection with soil-transmitted helminths 18-weeks post-treatment with albendazole-ivermectin, albendazole-mebendazole, albendazole-oxantel pamoate and mebendazole. Parasit Vectors. 2016;9:123. https://doi. org/10.1186/s13071-016-1406-8

PMid:26935065

16. Bethony J, Brooker S, Albonico M, Geiger SM, Loukas A Diemert $D$, et al. Soil-transmitted helminth infections: Ascariasis, trichuriasis, and hookworm. Lancet. 2006;367(9521):1521-32. https://doi.org/10.1016/s0140-6736(06)68653-4

PMid:16679166
17. Dayan AD. Albendazole, mebendazole and praziquantel. Review of non-clinical toxicity and pharmacokinetics. Acta Trop. 2003;86(2-3):141-59. https://doi.org/10.1016/ s0001-706x(03)00031-7

PMid:12745134

18. Tjay TH, Rahardja K. Antihelmentika. In: Obat-Obat Penting. $5^{\text {th }}$ ed. Jakarta, Indonesia: PT Elex Media Komputindo; 2005. p. 187-96.

19. Martin RJ, Geary RG. Pharmacology of pyrantel. In: Marchiondo AA, editor. Pyrantel Parasiticide Therapy in Humans and Domestic Animals. United States: Academic Press; 2016. p. 21-45. https://doi.org/10.1016/b978-0-12-801449-3.00013-2

20. Chin J. Manual Pemberantasan Penyakit Menular. Jakarta, Indonesia: Pemberatasan Penyakit Menular Langsung Ditjen PPM and PL Depkes RI; 2005.

21. Brooker S, Clements AC, Bundy DA. Global epidemiology, ecology and control of soil-transmitted helminth infections. Adv Parasitol. 2006;62:221-61. https://doi.org/10.1016/ s0065-308x(05)62007-6

PMid:16647972

22. Ziegelbauer K, Speich B, Mäusezahl D, Bos R, Keiser J, Utzinger J. Effect of sanitation on soil-transmitted helminth infection: Systematic review and meta-analysis. PLoS Med. 2012;9(1):e1001162. https://doi.org/10.1371/journal. pmed.1001162

PMid:22291577 